\title{
Influence of Cognitive Style on Students' Academic Achievement at Faculty of Economics, National University of Malaysia
}

Muhammad Hussin, Norhaslinda Mohd Razali, Agussalim M, SE., MS.

To Link this Article: http://dx.doi.org/10.6007/IJARBSS/v11-i3/8983

DOI:10.6007/IJARBSS/v11-i3/8983

Received: 20 January 2021, Revised: 18 February 2021, Accepted: 01 March 2021

Published Online: 16 March 2021

In-Text Citation: (Hussin et al., 2021)

To Cite this Article: Hussin, M., Razali, N. M., \& Agussalim, M., SE., M. (2021). Influence of Cognitive Style on Students' Academic Achievement at Faculty of Economics, National University of Malaysia. International Journal of Academic Research in Business and Social Sciences, 11(3), 762-771.

\section{Copyright: (c) 2021 The Author(s)}

Published by Human Resource Management Academic Research Society (www.hrmars.com)

This article is published under the Creative Commons Attribution (CC BY 4.0) license. Anyone may reproduce, distribute, translate and create derivative works of this article (for both commercial and non-commercial purposes), subject to full attribution to the original publication and authors. The full terms of this license may be seen at: http://creativecommons.org/licences/by/4.0/legalcode

Vol. 11, No. 3, 2021, Pg. 762 - 771

Full Terms \& Conditions of access and use can be found at http://hrmars.com/index.php/pages/detail/publication-ethics 


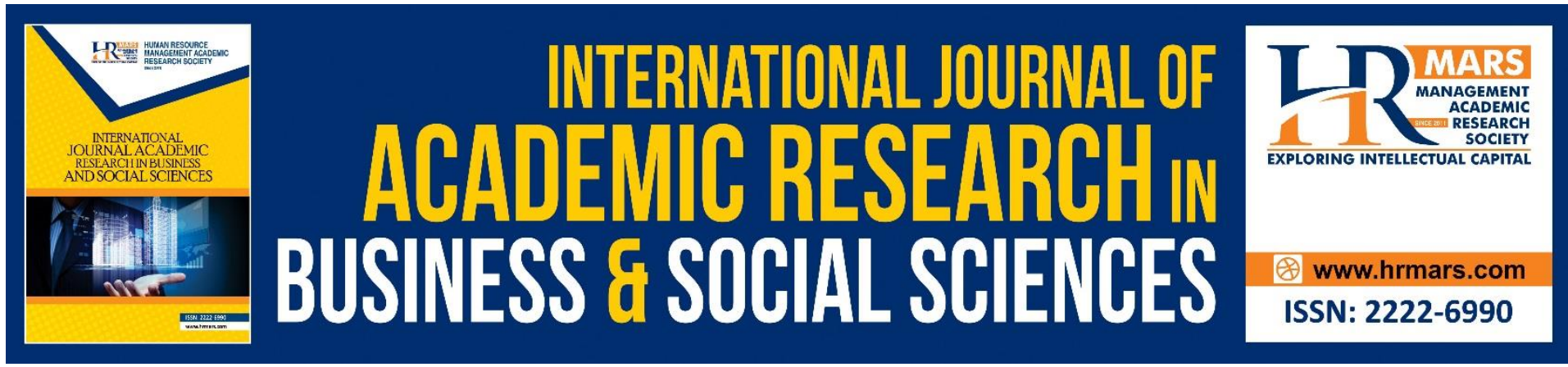

\title{
Influence of Cognitive Style on Students' Academic Achievement at Faculty of Economics, National University of Malaysia
}

\author{
Muhammad Hussin, Norhaslinda Mohd Razali \\ Faculty of Education, Universiti Kebangsaan Malaysia, 43600 Bangi, Malaysia \\ Email: banting99@hotmail.com \\ Agussalim M,SE., MS. \\ Management Study Program, Faculty of Economic, Universitas Ekasakti Indonesia \\ Email: agussalim20042017@gmai.com,muhsin@ukm.edu.my
}

\begin{abstract}
This study aims to explore the relationship between the cognitive style and academic achievement for students in Year One of the Faculty of Economics at the National University of Malaysia. Furthermore we also explore the relationship between students background and their achievement. On the other side, the cognitive style is divided into two dimensions whether it is 'Field Independent 'or' Field dependent'. A total of 100 first year students were tested. The measurement tool used was a questionnaire consisting of the background of the students, academic achievement and cognitive style and other factors that have effect on student's achievement. In general, academic achievement was not affected by gender. While the race factors show that the performance of Chinese students are better than the Malay and other races. However, for the Chinese and Indians, there were no inherent differences in achievement. Study also shows that the correlation coefficient had a positive relation. This means that student's academic background influence student achievement for first year students. In terms of cognitive style, the students with analytical cognitive styles (Field Independent) has better achievement than students of global cognitive styles (Field dependent).
\end{abstract}

Keywords: Academic Achievement, Cognitive Style, Field Dependent, Field Independent, Gender.

\section{Introduction}

The national education system in Malaysia has undergone a transformation towards advancement and enhancement. Changes that occur from time to time show the mature view of the Ministry of Education and sensitivity to the challenges and current needs. The impact of globalization, liberalization and development of information and communication technologies provide internal and external challenges.

In the era of globalization towards achievement, learning plays an important role in human life. Without excellence in education, it is difficult for humans to change their socio- 
economic status. Gage and Berliner (1975) stated that learning is a process that leads to changes in behaviour resulting from experience. This includes information in terms of facts, concepts, practices, thinking skills, habits and behaviour.

Orientation and learning purposes of a student differ from each other. Some students are influenced by motivation, attitude and cognitive style. There are also students who are affected by family background and interests. Thus, the students' achievement in academic is often associated with orientation and learning purposes. High orientation on achievement according to Jelas (1998) requires students to gain meaning from what they have learned and to reproduce what they have learned according to the course and lecturers who teach these courses.

Entwistle (1987) also takes into account the work carried out by Pask (1976) to develop models of learning in higher education. To understand what they are learning, students use different learning strategy based on the style of their choice. Effective learning requires a versatile learning style approach where the internal style (deep approach) integrates 'holist' style and at the same time use the 'serialist' style to examine in detail the fact that the meaning of relevance and relationships to create the impression of an idea or concept that can be carried out. 'Holist strategy 'will produce the level of understanding associated with passive internal approach, while the 'serialist' strategy associated with the external approach (surface approach). Nevertheless, the 'serialist' strategy involves the construction of meaning from the fact content, while the external approach shows characteristics of memorization. Students who have a tendency towards 'holist' or 'serialist' alone will show pathological features of learning.

The effectiveness of learning in higher education is often reflected in grades and cumulative grade point average (CGPA) achieved by the students. Learning involves the cognitive processes and the use of information processing strategy which prepare students to solve problems or answer questions in the exam. Background, motivation and cognitive style have been identified by many educational psychologists as the key element in determining the effectiveness of the learning process.

At the National University of Malaysia, students who achieve a CGPA of 3.5 above are categorized as a brilliant student. It is assumed that students who achieve this have an outstanding level of effective learning skills when compared to low achievers (Trigwell, 1991). In order to help low achievers' students excel, it is important for lecturers to encourage students to use learning strategies that are versatile and effective and thus this will lead them to achieve higher performance.

However, people are often under assumption that Malay university students' performance was weaker against non-Malay students. It was alleged that young Malay fail to meet their own quotas in IPTA when there are hundreds of "qualified non-Malay" students fail to get a place at the university. However unfulfilled Bumiputera quota vacancies allegations are unfounded and had never happened because the number of Bumiputera students who excel in academics every year always increases.

This study aims to explore the extent to which background factors and cognitive style influence towards their academic achievement of year two students of the Faculty of Economics at UKM. Specifically, the first objective of the study is to explore the students' cognitive styles. Next is to explore the influence of students' gender, race and cognitive styles on academic achievement. 


\section{Literature Review of the StudyInfluence of Students Demographic Factors on Academic Achievement}

Huss and Kayson (1985) in their study on the effects of gender and speed of finding hidden figures in the TEFT (The Embedded Figure Test) test. A total of 20 male and female students voluntarily participated in this study. Students ranging from grades 3-4 and grades 11-12. Every student is given instructions and they are evaluated based on the ability to find a simple geometric shape hidden in the complex diagrams. Data analysis found that the effect of gender and students' grade is significant. Male students can find hidden pictures faster than female students. While the 11-12 grade students were more quickly to find the hidden pictures compared to grade 3-4 students.

Baba and Chong (1993) argued that gender backgrounds affect their academic performance. Mebare and Johnson (1976) also found from a study on Mexican children that different cognitive style exists among the sexes. The study found there were differences that exist between men and women. Male students were said to have cognitive styles that are Field Independent than female students. Study by Wong (1982) on 180 Anglo American children discovered Anglo American boys are more Field Independent compared to Chinese and Mexican-American girls.

According to Moss (1982), a study on race to determine the learning process among those with basic skills in university and its relationship with academic achievement shows no significant relationship between academic achievement and learning process among the subjects. There were past findings that strong accomplishments factor were influenced by one's past successes. Keeves (1975) as well as Okpale and Onocha (1988) found that student achievement in mathematics at university were due to their outstanding achievements in previous achievement.

Studies also shows that race background influence student achievement. In a survey conducted by Elias (1995), it was found that the Chinese students' performance in qualitative and quantitative courses was higher than the Malay students. This study is based on the Thematic Apperception Test (TAT) which is used to measure achievement motivation and problem solving. In problem solving, it was discovered that Chinese students had higher achievement than Malay students. This may be due to the learning activities in the form of discussions help them to improve performance in exams. This may also be because of the values of a simple life of the Chinese people to accept change than the Malays who are trapped by their traditional values.

\section{Research on the Influence of Cognitive Styles on Academic Achievements}

Cognitive style is how individual process information. Gage and Berliner (1975) divide cognitive style into two dimensions i.e. namely Field Independent and Field Dependent. Field Dependent refers to global perception and Field Independent refers to the perception analytically. Piaget (1950) argues that cognitive styles affect students in terms of learning. While Feiji (1976) study shows that students who are Field Independent excelled better than those who are Field Dependent. Satterly (1976) research also shows that cognitive style of Field Independent were more successful in science and mathematics. Nordin (1985) found from his research that cognitive styles also influence student achievement in language skills and knowledge.

Witkin (1964) argued that cognitive style can be said to be the characteristics of manners and self-consistency showed by individuals in intellectual activities and their observations. Two dimensions of cognitive style identified by Witkin, Goodenough, and Karp (1967) is the 
dimension of 'Field Dependant 'and' Field Independent'. Dependant field reflects the individual observations which are limited and rather comprehensive and Field Independent means someone who can clearly make observations, the differences are small and more precise observed to be that of analytical nature.

Apart from background and cognitive style, other factors also influence academic achievement. This happen when students are interested in the subject and they tend to work hard to achieve a high level of achievement. According to Hannabuss (2000) the library is a key driver for the development of literacy and promote reading habit among children of all ages. Other factor such as attitudes of students also influences academic achievement. Usually for those who aspire to improve their living standards of their family would work vigorously towards education. According to Saracho and Dayton (1991) the initiative to read were influenced extremely by non-cognitive factors such as interests, attitudes and motivation.

Motivation also influences academic achievement whether it is intrinsic or extrinsic (Meng, 1996). Intrinsic motivation exists from within an individual such as personal satisfaction. Instead, extrinsic motivation comes from external motivation, for example to get excellent grades or intended to secure positions. From a survey conducted by Elias (1995) according to the theory of achievement motivation, motivated individuals seeking high achievement were able to create something that meets the standard of excellence. Results of this study was supported by Ashton and Webb (1986), who found that achievement motivation training has enhanced the creativity of subjects in the experimental group.

\section{Research Design}

This study utilised a survey method to observe the influence of students' background and cognitive style on their academic achievement of year one students at the National University of Malaysia (UKM). There are two main variables involved i.e. the background and the cognitive style as the dependent variable and the achievement as an independent variable. The population of the study consists of first-year students of the Faculty of Economics at UKM. The study sample were randomly selected from 4 types of races i.e. the Malays, Chinese, Indians and other races. Other races include those such as Iban, Orang Asli and others. This study consists of students with low and high achievement. The students who are high achieving consists of those with PGNK 3.0 and above. While the low achieving ranges from 2.99 and below. In terms of gender, there are 40 male and 60 female students which made up of $54 \%$ Malays, $36 \%$ Chinese, $8 \%$ Indians and $2 \%$ from other races.

This researchers used questionnaire to study the background of students and achievement. There are three areas studied. Appendix A consists of student background information, i.e.; age, gender, race and parental background. Appendix B consists of academic achievement and prior performance. Part $C$ includes cognitive style and other factors that influence achievement. There are 20 questions in the form of multiple choice of the likert scale. This scale made up of 1 to 5 from strongly disagree to strongly agree.

\section{Results and Discussion}

\section{Study on Achievement of First Students}

From the t-test data (Table 1), the study shows that there are several items that affect the achievement of year one students in UKM. Students were found to be more to independent cognitive style and they prefer to express opinion, like to make their own additional training, like making own research, often meet with the lecturer if they do not 
understand the title, hoping to get excellent results, like making your own reference in the library, like calculation-based subjects etc. This is due to significant value less than 0.05 . This means that the null hypothesis is rejected and there is no significant relationship between achievement and cognitive style on certain pairs.

According to Piaget (1950) cognitive styles influence students in terms of learning. In addition, Feiji (1976) also conducted a study on 60 psychology students found that students who in nature field independent perform better than field dependent in nature. In addition, according to Satterly (1976) showed that field independent cognitive styles students are more successful in science and math subjects. Nordin (1985) also found from his study discovered that cognitive style influence student achievement in language skills and knowledge.

Therefore, it can be concluded that those who have a field dependent cognitive style prefer to think creatively and interested in the lessons that require them to think. Meanwhile those who are field independent in nature also behave analytically, likes math, like to make their own research, love to make their own additional training, often meet lecturers etc. From the research, we found that most of the high achieving UKM students has field independent cognitive style. While those of low achievers have a more field dependent cognitive style.

Table 1

Paired Samples Test

\begin{tabular}{lllll}
\hline & t & df & Sig. (2-tailed) \\
\hline Pair 1 & Year 1- Cognitive Style 1 & -1.326 & 99 & .188 \\
Pair 2 & Year 1- Cognitive Style 2 & 4.527 & 99 & .000 \\
Pair 3 & Year 1- Cognitive Style 3 & 7.940 & 99 & .000 \\
Pair 4 & Year 1- Cognitive Style 4 & 0.890 & 99 & .376 \\
Pair 5 & Year 1- Cognitive Style 5 & 6.784 & 99 & .000 \\
Pair 6 & Year 1- Cognitive Style 6 & 7.645 & 99 & .000 \\
Pair 7 & Year 1- Cognitive Style 7 & 5.682 & 99 & .000 \\
Pair 8 & Year 1- Cognitive Style 8 & 0.961 & 99 & .339 \\
Pair 9 Year 1- Cognitive Style 9 & 4.021 & 99 & .000 \\
Pair 10 Year 1- Cognitive Style 10 & -1.028 & 99 & .302 \\
Pair 11 Year 1- Cognitive Style 11 & -0.741 & 99 & .461 \\
Pair 12 Year 1- Cognitive Style 12 & 18.02 & 99 & .000 \\
Pair 13 Year 1- Cognitive Style 13 & -0.362 & 99 & .718 \\
Pair 14 Year 1- Cognitive Style 14 & -2.345 & 99 & .021 \\
Pair 15 Year 1- Cognitive Style 15 & -3.624 & 99 & .000 \\
Pair 16 Year 1- Cognitive Style 16 & 1.789 & 99 & .077 \\
Pair 17 Year 1- Cognitive Style 17 & 2.451 & 99 & .016 \\
Pair 18 Year 1- Cognitive Style 18 & 6.101 & 99 & .000 \\
Pair 19 Year 1- Cognitive Style 19 & 2.956 & 99 & .004 \\
Pair 20 Year 1- Cognitive Style 20 & 1.275 & 99 & .205 \\
& & & & \\
\hline
\end{tabular}

\section{Relationship Between Prior Achievement and Achievement in Year 1}

Pearson correlation analysis discovered significant relationship between prior achievement in SPM and achievement in the first year, significant at $P<0.05$. From the results, it appears that correlation coefficient for the pair variable of prior achievement and the achievement for the first years in UKM is positive (Figure 1). 


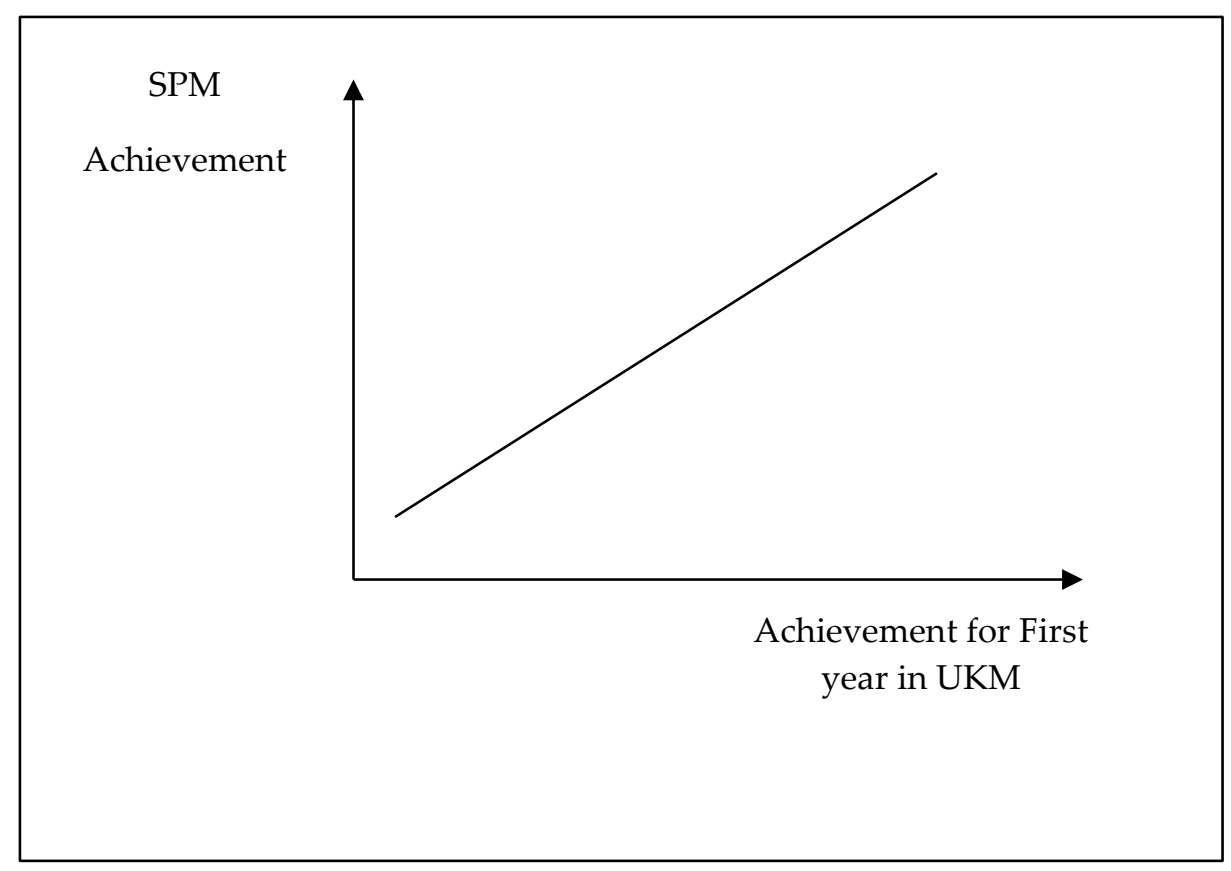

Figure 1. Relationship Between Background and Achievement in SPM and Achievement for the First Years in UKM.

\section{Research on Relationship Between Gender and Achievement}

Research on the influence of gender backgrounds on achievement found no significant difference in achievement among male and female students. This finding were supported by the study conducted by Baba and Chong (1993), Mebare and Johnson (1976), as well as Wong (1982). Based on the mean differences, it showed that boys and girls do not differ much in terms of achievement.

\section{Research on the Relationship Between Race and Achievement}

Studies of the achievement among the Malays and Chinese shows that there are significant difference in achievement among races. Elias (1995) also found that there are significant difference between Malay and Chinese students in terms of achievement. Chinese students had better performance than Malay students. This may be due to Chinese students who were easily adapt to changes compared with the Malay students who are bound by traditional values.

Study also found no significant difference in achievement between the Malay and Indian. Malays and Indians are the same in terms of performance. The Malays and other races also showed no significant difference in achievement. Despite this, the value of the t-test showed positive correlation coefficient.

For the study of prior achievement between Chinese and Indian, we found no significant differences between the Chinese and Indian. This shows that the Chinese and Indian races are equal while the achievement of the Chinese race and other races are not equivalent.

\section{Study on Cognitive Styles Toward Student Achievement}

The study found that out of the 20 items, 12 items have the value of $P<0.05$. This shows that there is a significant difference between cognitive style and achievement. From the $t-$ test it can be concluded that the achievement of student in year one is influenced by the 
cognitive styles of the students. We find those who like math like practising on their own, likes to make their own research, often meet with lecturers, have higher intrinsic motivation, likes making their own reference, understand the mathematic teachings and loves calculation is the cognitive style "field independent" in nature. Those who love to talk, love forming their own group research, not caring about the results of the examination and are influenced by the parents are "field dependent". This suggests that those with cognitive style "field independent" have a higher achievement than those who have the cognitive style "field dependent".

Apart from cognitive style, other factors also influence student achievement such as attitude and motivation. Attitudes of students who work hard and hope for good results as well as receiving motivation from parents is also a reason for high academic achievement. Intrinsic and extrinsic motivation factors also affect achievement in education. According to the theory of motivation achievement of individuals who have high motivation are able to create something unique and meet the standards of excellence. These results are supported by Ashton and Webb (1986) who found that motivation achievement training has raised the subjects' creativity in the group. Interest in a subject also affect student achievement because of their love of mathematics tend to have higher achievement than those who are not interested in math.

\section{Conclusion}

The overall study found that achievement is not affected by gender. But for the factors of race, Chinese students' achievements are better than the achievement of the Malays and other races. While for the Malay and Indian students' achievement, study shows there was no difference in terms of achievement. Study also found that there are significant influence of cognitive style on students achievement. Based on this findings, its is best to suggest the following:

a) Lecturers teaching must be in accordance with students' cognitive styles

b) Students need to be motivated in learning because it affects achievement

c) Future studies should emphasize the student metacognition, motivation and attitudes in influencing achievement

d) The research should emphasize on students' learning styles in influencing achievement

Everyone has their own preferred cognitive style as a result of various influences. Opinion stating that students need to adapt to the lecturers' teaching style was neglacting the biological cognitive style naturally. They also deny the findings of Cafferty (1980) who stated that the better the matching between the teachers' style and the students' style, the higher the grade point average, and vice versa. Educators should understand that cognitive style should not be considered insignificant.

The importance of the need to identify the cognitive style, which is the foundation of teaching, become more apparent when educators are facing with the issue of student diversity that has a wide range of needs. To identify the cognitive style of students, educators should use instruments to measure cognitive style with reliability and validity. If students are given the opportunity to learn according to their own cognitive style, students will often get higher achievement in the subject. The opposite will happen if teaching students is not precise with the cognitive styles (Curry, 1987). No learning style is better or any better than the other. Each learning style has the same range of intelligence. Therefore, students should not be labelled as to cast a stigma for having a specific learning style. Most students pursuing a 
teaching session, can achieve the advanced level in their studies. However, how they reach the advanced level depending on each individual's cognitive style.

Ideal theoretical concept, if practicable, suitable only for a handful of students. This approach is more effective when monitoring can be implemented individually. A more comprehensive study in this field, in order to improve the quality of teaching and learning needs to be look further.

Everyone has their own preferred cognitive style as a result of various influences. Opinion stating students need for adaptation of their lecturers teaching style deny biological cognitive style that were more natural. They also deny the findings of Cafferty (1980) stating that the better matching of the lectures style and the students' style, the higher the grade point average, and vice versa. Educators should understand that cognitive style should not be considered insignificant. Cognitive style is a great resistance to change.

The need to identify cognitive styles is the foundation of teaching and has become more apparent when educators are faced by the issue of student diversity that has a wide range of needs. To identify the cognitive style of students, educators should use instruments to measure cognitive style with reliability and validity. If students learn something difficult, they will often get higher achievement and a measurement in attitude in the same subject. The opposite will happen if teaching is not in precision with students' cognitive styles (Curry, 1987).

In higher education for both public and private universities, the demands for critical thinking is crucial. The vague purpose of this will be much easier if it was conceptualized in the model of learning in which the concentration is on the things that need to be known for a higher understanding. If the purpose clear, the means of achieving that goal may be considered. The starting point in giving definition to the teaching situation in higher education is often the formation of a course itself. What are the skills, concepts, knowledge, ideas and levels of understanding of the students? What is the expectation for the students at the end of the course? All this is not grasped by the writing of the syllabus of a particular course. Having set goals will give specific and accurate courses, students need to be told what is expected from them in a specific and clear form. Is there any other way for them to know what learning strategies should be used? How they can achieve something that is not clearly explained? However, this approach is rarely used in higher education. If practiced, the students are able to use this knowledge as much as possible.

No learning style is better or no better than the other. Each learning style has the same range of intelligence. Therefore, students should not be labelled as to cast a stigma for having a specific learning style. Most students taking a teaching session, can achieve the advanced level in their studies. However, how they reach the advanced level depends on each individual's cognitive style.

\section{References}

Ashton, P. T., \& Webb, R. B. (1986). Making a Difference: Teachers' Sense of Efficacy and Student Achievement. New York: Longman.

Baba, A., \& Chong, M. L. (1993). Hubungan di antara stail kognitif dengan jantina, aliran dan kesannya terhadap pencapaian akademik pelajar. Jurnal Pendidikan, 17, 61-73.

Cafferty, E. I. (1980). An analysis of student performance based upon the degree of match between the educational cognitive style of the teacher and the educational cognitive style of the students. (Unpublished doctoral dissertation). University of Nebraska, Lincoln. 
Curry, L. (1987). Integrating concepts of cognitive or learning style: A review with attention to psychometric standards. Ottawa: Canadian College of Health Service Executives.

Elias, H. (1995). Latihan Motivasi pencapaian dan kesannya ke atas prestasi peperiksaan: Kebiasaan belajar dan sikap pelajar-pelajar peringkat universiti. Jurnal Pendidikan, 17.

Entwistle, N. J. (1987). A model of the teaching-learning process. In J.T.E. Richardson, M.W. Eysenck, D.W. Piper (Eds.), Student Learning: Research in Education and Cognitive Psychology (pp. 13-28). London: Open University Press.

Feiji, J. A. (1976). Field independence, impulsiveness, high school training and academic achievement. Journal of Educational Psychology, 68, 793-799.

Gage, N. L., \& Berliner, D. C. (1975). Educational Psychology. Chicago: Rand McNally College Publishing Company.

Hannabuss, S. A. 2000. Place for Children: Public Libraries as a Major Force in Children's Reading. Library Review, 49, 252-260.

Huss, E. T., \& Kayson, W. A. (1985). Effects of age and sex on speed of finding embedded figures. Perceptual and motor skills, 61, 591-594.

Jelas, J. M. 1998. Laporan Akhir Penyelidikan G3. Malaysia.

Keeves, J. P. (1975). The home, the school, and achievement in mathematics and science. Science Education, 59, 439-460.

Mebara, D., \& Johnson, D. L. (1976). Comparison of the performance of Mexican boy and girls in Witkin's Cognitive Task. International Journal of Psychology, 4, 227-239.

Meng, E. A. (1996). Perkembangan Aplikasi Dalam Bilik Darjah. Kuala Lumpur, Malaysia: Fajar Bakti Sdn Bhd.

Moss, C. J. (1982). Academic achievement and individual differences in the learning processes of basic skills students in the university. Applied Psychological Measurement, 6, 291-296.

Nordin, A. B. (1985). Kesan stail kognitif ke atas pencapaian Bahasa Malaysia. Jurnal Pendidikan, 10-11, 3-15.

Okpale, P., \& Onocha, C. (1988). Student's factors as correlates of achievement in physics. Physics Education, 23, 361-364.

Pask, G. (1976). Styles and strategies of learning. British Journal of Educational Psychology, $46,128-148$.

Piaget, J. (1950). The psychology of intelligence. London: Routledge.

Saracho, O. N., \& Dayton, C. M. (1991). Age-related changes in reading attitudes of young children: A cross-cultural study. Journal of Research Reading, 14, 33-45.

Satterly, D. J. (1976). Cognitive styles, spatial ability, and school achievement. Journal of Educational Psychology, 68, 36-42.

Trigwell, K., \& Prosser, M. (1991). Improving the quality of student learning: The influence of learning context and student approaches to learning on learning outcomes. Higher Education, 22, 251-266.

Witkin, H. A. (1964). Origins of cognitive style. In C. Sheerer (Eds.), Cognition: Theory, Research, Promise. New York: Harper and Row

Witkin, H. A., Goodenough, D. R., \& Karp, S. A. (1967). Stability of cognitive style from childhood to young adulthood. Journal of Personality and Social Psychology, 7, 291-300.

Wong, P. (1982). Relationship of two Field Independent Measures to Reading and Mathematics Achieves of Anglo American Figure Generation Chinese and Mexican American Elementary School Children (Dissertation). Retrieved from Abstract International Dissertation. (43: $1023 \mathrm{~A})$. 